УДК 629.463.65.027.2

S. MYAMLIN ${ }^{1}$, L. NEDUZHA ${ }^{2}$, O. TEN $^{3}$, A. SHVETS $^{2}$

${ }^{1}$ Vice-Rector, The Dniepropetrovsk National University of Railway Transport named after Academician V. Lazaryan, Lazaryan Str., 2, 49010, Dniepropetrovsk, Ukraine, tel./fax +38 (056) 79319 03, e-mail sergeymyamlin@gmail.com

${ }^{2 *}$ Department of Structural Mechnics Chair, The Dnipropetrovsk National University of Railway Transport named after

Academician V. Lazaryan, Lazaryan Str., 2, 49010, Dnepropetrovsk, Ukraine, tel./fax +38 (056) 793 19 03, e-mail nlorhen@i.ua

${ }^{3}$ Promtractor-Wagon CJSC, 429332, Kanash, Illicha Str., 1a, Russia, tel./fax +78 (83533) 255 65, e-mail kvrz@cbx.ru

\title{
DETERMINATION OF DYNAMIC PERFORMANCE OF FREIGHT CARS TAKING INTO ACCOUNT TECHNICAL CONDITION OF SIDE BEARERS
}

Purpose. The railway transport plays an important role in social and economic life of the country and carries out the large containment of transportation activities. The transport industry should migrate towards innovation changes and increase its significance as an important transit subsystem on the way of renovation of both the infrastructure and the strategy of all transportation process components including the interaction with other transport modes. At present the life sets strategic challenges for the railway branch, and the basic goals among them are as follows: high-speed train traffic development, increase of the weight of freight trains, new rolling stock development etc. Due to the urgency of this subject, the researchers should cope with the task devoted to one of aspects of improving the freight transportation efficiency, namely to the study of effects of various factors and characteristics of technical conditions of the freight cars running gears (which are unavoidable to arise during operation) on their basic dynamic indices. The deviations of technical conditions of running gears from the normal state of the wedge system of bogie swing suspension also play an important role among them. The purpose of the paper is to investigate the influence of different factors of the technical conditions of freight car running gears (size deviation in both the bearers and the wedge system during operation) on their basic indices - coefficients of horizontal and vertical dynamics, vehicle body acceleration, frame strength, and derailment stability coefficient. Methodology. The study was conducted by numerical integration and mathematical modeling of the freight car dynamic loading using the software package "Dynamics of Rail Vehicles" ("DYNRAIL"). Findings. As a result of the research for freight car dynamic coefficients determination taking into account technical conditions of the side bearers, the dependencies of the basic freight cars dynamic coefficients on the parameters of side bearers (the clearances in the side bearers and the wedge system conditions of the bogie swing suspension) considering running speed in the tangent and curved track sections of minor and mean radii were obtained. Originality. The impact of the technical condition of the car running gears on the traffic safety factors is determined. Practical value. The theoretical research results in determination of freight car dynamic indices taking into consideration the technical conditions of the side bearers of freight cars allow for an adequate assessment of effect of the freight car bogies' technical conditions, namely the bearers parameters, on the railway traffic safety factors (coefficients of horizontal and vertical dynamics, vehicle body acceleration, frame strength and derailment stability coefficient).

Keywords: freight cars; bogie side bearers; running speed; tangent and curved track sections; dynamic coefficients

Introduction. Railway Transport of Ukraine plays an important role in social and economic life of our country and the large containment of transportation activities (its share in the total freight turnover is about $85 \%$ and passenger turnover share is $45 \%$ - Ukrainian railways are the fourth in Eurasia and the sixth in the world rank in good transportation volume) when only $2 \%$ of the total working population works on the railway transport. [3].

This confirms that the transport industry should migrate towards innovation changes and increase its significance as an important transit subsystem on the way of renovation of both the infrastructure and the strategy of all transportation process components including the interaction with other transport modes.

At present, life sets strategic challenges for the railway branch; the basic objectives among them are as follows:

- high-speed train traffic development;

- new rolling stock development and moderniza- 
tion of the operated car fleet;

- increase of freight trains weight (due to using cars with increased loadings per axle and introduction of multicar trains);

- reconstruction of the railway infrastru-cture;

- improvement of the railway transportation technology, as well as its quality improvement, including the organization of container and contrailer transportations;

- traffic safety increase;

- improvement of technical and economic performance of railway operation due to migration towards innovative way of the rolling stock construction.

It is clear that these and other tasks may be implemented only on the basis of innovative technical decisions, technologies, scientific researches, engineering developments, the railway industry of Ukraine is oriented on in prospect.

Urgency. In November 2005 by the decision of authorized experts of car facilities of Railway Transport Commission of CIS and Baltic countries two projects of freight car modernization were approved [7]. According to this decision in Ukraine about 42 thousand of cars were modernized, the largest amount of which are open cars (Fig. 1).

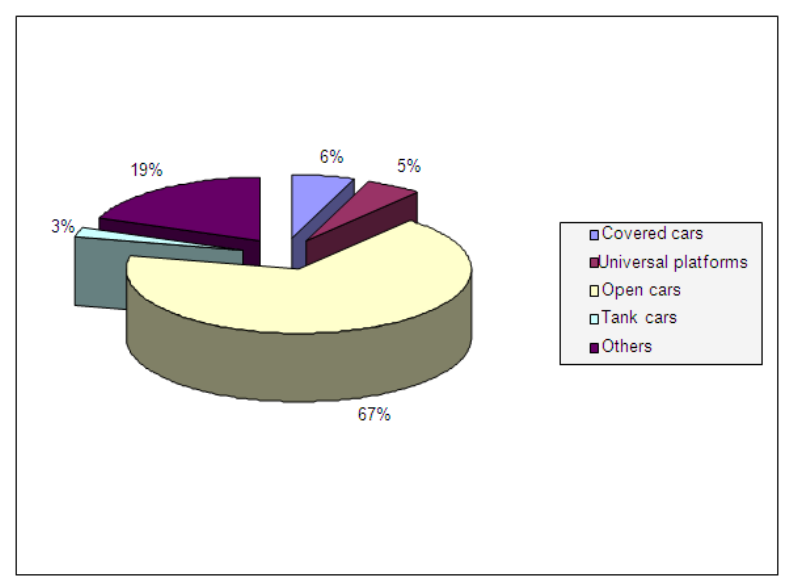

Figure 1. Data of car modernization

Modernization of the freight car bogies is performed for both the repair costs reduction and improvement of the technical and economic performance in operation. Modernization involves the use of bearing (for bogie 18-100) ISB-12C, CCB and Preloud Plus, as well as spacer installation into the center pad, friction wedge with polyurethane plate and friction plate. Modernization with the use of wear-resistant elements allows increasing the overhaul life of cars from 110 to 160 thousand of $\mathrm{km}$. The interrepair time is also assumed to increase from 2 to 3 years.

Basic requirements for the construction of a new generation cars according to the "Program of rolling stock renovation" are the requirements that allow reducing the operating costs and enhancement the economic effectiveness of their use, taking into account scientific and technical progress.

Problem definition. Owing to the urgency of this subject, the task of scientists is devoted to one of the aspects of freight transportation efficiency enhancement, namely to the study of the various factors influence and characteristics of technical state of the freight cars running gears (which are bound to arise during operation) on their basic dynamic parameters. The technical state of running gears deviations from normal condition of the wedge system of the bogie swing suspension also play an important role among them.

The famous domestic scientists have already carried out the research of the impact on the dynamic qualities or the wheel wear (Doctor of technical sciences, Professor Ye. P. Blokhin, V.D. Danovych, Yu. V. Demin, M. L. Korotenko, O. M. Savchuk, V. F. Ushkalov).

Theoretical researches were conducted in motion of the empty and loaded freight cars with the bogie TsNII-Kh3 in the tangent and curved track sections of different radii with the given running speed. The study was conducted by numerical integration and mathematical modeling methods of the freight car dynamic loading using the software system "Dynamics of Rail Vehicles" ("DYNRAIL").

Main part. It is commonly known, that the setting of permissible car speeds in the tangent and curved track sections is a hard engineering task, which requires differential approach and takes into account the technical condition of the track superstructure (TS) and the running gears of the rolling stock [2].

The results of the permissible speeds setting (on the basis of the previous researches) are presented in the form of histograms for tangent and curved track sections (Fig. 2, b - numeration of the track superstructure types according to the Table 1), which demonstrate the distribution of the running speed values, depending on the track superstructure (for tangent track sections) or on the curve radius and 
the type of the track superstructure (for curved track sections). According to these data the most durable of the chosen superstructure types are the R65(6) 1840, 2000Shch, Gr, P and heavier tracks, which allow moving with $90 \mathrm{~km} / \mathrm{h}$ in both the curved and the tangent track sections. The use of these track marks allows motion in the minor radius track section with the speed $70 \mathrm{~km} / \mathrm{h}$, which is much higher in comparison with the other marks.

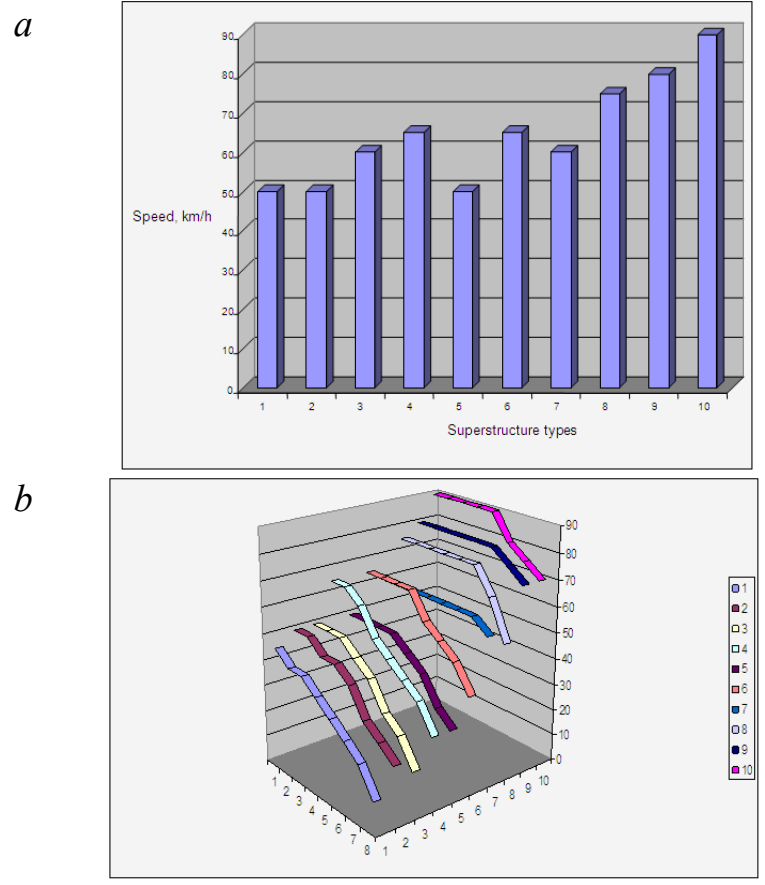

Fig. 2. The running speed value, depending on the track superstructure for tangent (a) and curved (b) track sections

The permissible running speeds were set on the results of dynamic coefficients with their permissible values. The current recommended and permissible dynamic coefficients of the cars according to the "Standards" [5] are presented in the Table 2.

Wheels take the highest horizontal transverse forces from the tracks in the curved track sections [1]. These forces, especially in the minor radii curves, can for several times exceed the forces, arising during the vehicle hunting in the tangent track sections. A considerable amount of accidents and train wrecks caused by the lack of durability of the track or rolling stock construction, as well as the loss of their resistance happens in the curved track sections.

The values of the vertical and horizontal dynamics coefficients, resistance coefficient, the di- rective, side and frame forces during the vehicle motion in the curves, are necessary for the durability calculations of the track and rolling stock construction, for determination of the minimum radii of the curves, in which certain vehicles can be passed, as well as for the calculation of their resistance.

Table 1

\section{TS Types}

\begin{tabular}{c|l}
\hline $\mathrm{N}$ & \multicolumn{1}{|c}{ Superstructure type } \\
\hline 1 & $\mathrm{R} 43(6) 1600 \mathrm{P}$ \\
\hline 2 & $\mathrm{R} 430(6) 1840,2000 \mathrm{P}$ \\
\hline 3 & $\mathrm{R} 43(6) 1600 \mathrm{Gr}$ \\
\hline 4 & $\mathrm{R} 430(6) 1840,2000 \mathrm{Gr}$ \\
\hline 5 & $\mathrm{R} 43(6) 1600$ Shch \\
\hline 6 & $\mathrm{R} 43(6) 1840,2000 \mathrm{Shch}$ \\
\hline 7 & R50(6) 1600 Shch, Gr, P \\
\hline 8 & R50(6) 1840, 2000 Shch, Gr, P \\
\hline 9 & R65(6) 1600 Shch, Gr, P \\
\hline 10 & R65(6) 1840, 2000 Shch, Gr, P, and hevier
\end{tabular}

Table 2

\section{The permissible dynamic coefficients for the freight cars}

\begin{tabular}{c|c|c}
\hline Criterion & Loaded car & Empty car \\
\hline$[$ VDC $]$ & 0.8 & 0.85 \\
\hline$[\mathrm{HDC}]$ & 0.4 & 0.4 \\
\hline$[\mathrm{CR}]$ & 1.3 & 1.3 \\
\hline$\left[\mathrm{H}_{\mathrm{p}} / \mathrm{P}_{\mathrm{o}}\right]$ & 0.3 & 0.38 \\
\hline$[\mathrm{ah}]$ & 0.3 & 0.3 \\
\hline$[\mathrm{av}]$ & 0.6 & 0.7
\end{tabular}

Dynamic forces, affecting the car depend on many reasons. One of them is elastic and dissipative characteristic in swing suspension.

Theoretical calculations dedicated to the impact research of different factors of the running gears technical condition of the freight cars (which are unavoidable to arise during operation) on their basic dynamic coefficients. The clearances between bearers and the deviations of technical conditions of running gears from the normal state of the wedge system of bogie swing suspension also play an important role among them.

The ability of the different bearer's type fitting in the construction of the freight cars bogies in the system of the body mounting on the truck bolsters 
is provided [8]. In the majority of cases on the four-wheel freight car bogies on the post-Soviet space as the simplest ones the hard bearers are being used. They are placed with the clearance between the bogie bearer and the vehicle body, which allows swaging the vehicle body on the center plates till this clearance exists.

During the wedge dampeners of the friction force operation with the relative vertical and horizontal movement of the surfaces the friction of the wedges 1 on the friction plates 2 arises (Fig. 3).

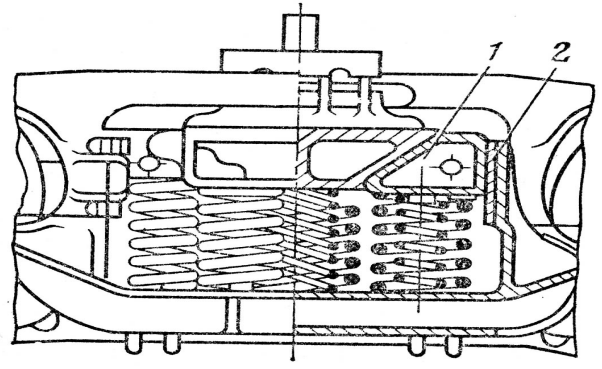

Fig. 3. Installation diagram of bearers on the bogie $18-100^{\wedge} 1$ - wedge, 2 - friction plate

Size deviations in both the bearers and the wedge system, undoubtedly, influence the change of the car values. The level of this influence will be examined further.

Results. Theoretical researches of the influence of bearer clearances on the freight car dynamic loading were conducted with nominal clearances in all four bearers, equal to $5 \mathrm{~mm}$. This means that the total clearance on both sides of the car ends equaled $10 \mathrm{~mm}$. Permissible clearance in the freight car depot repair is $6-16 \mathrm{~mm}$ in total for all types of eight-wheel cars except hoppers and dumpcars, for which this value is equal to $6-12$ $\mathrm{mm}$.

During calculation the clearances between bearers to $12.5 \mathrm{~mm}$ (i.e. $25 \mathrm{~mm}$. in total that exceeds the permissible depot repair value but occurs in operation) were examined.

In Fig. $3(a-b)$ the resulted values of dynamic performance of the vertical dynamics coefficients (VDC) and coefficient of resistance against the wheel mounting of a wheel on a rail, as well as framed force value $\mathrm{Hp}$ and the vertical acceleration value in the center plate zone $\mathrm{Zp}$ during the open car motion in a curve with radius of $600 \mathrm{~m}$.

The obtained results show that VDC and CR are higher than permissible values (Table 2). How- ever, Zp value significantly increases with the running speed of 80 and $90 \mathrm{~km} / \mathrm{h}$ and reaches the maximum value with $2,5 \mathrm{~mm}$ clearance. Perhaps, it is reasonable to reduce the permissible speed of 90 $\mathrm{km} / \mathrm{h}$ to $75 \mathrm{~km} / \mathrm{h}$ (Fig. $4-5$ ).

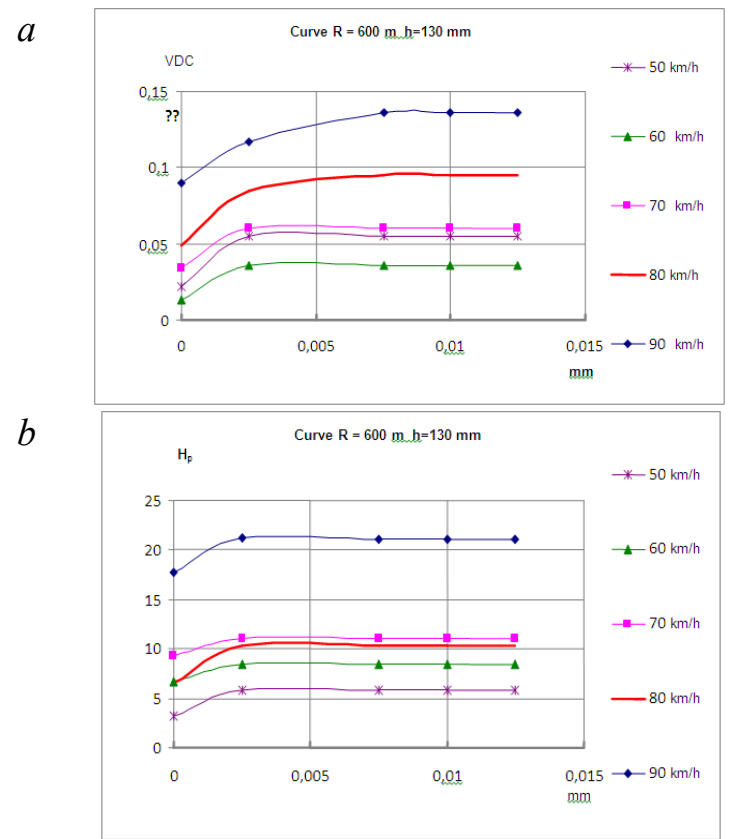

Fig. 4 Dependence of the vertical dynamics coefficients (a) and the framed force of freight car on the clearance in the bearers during motion in the curve with radius $600 \mathrm{~m}$

In the Fig. 6-7 the similar values of the dynamic values during car motion in the curve with radius of $350 \mathrm{~m}$ are given. The results show that VDC and CR values are also higher than minimal permissible values (Table 2). The framed force value is almost 1.5 times exceeds the values obtained for the curve with $600 \mathrm{~m}$ radius, and the acceleration in the center plate zone is not a stable value when the running speed is $70 \mathrm{~km} / \mathrm{h}$. The permissible running speed in the minor radius curves should be considered at the level $65 \mathrm{~km} / \mathrm{h}$ (Fig. 2, b).

The simultaneous increase or decrease of clearances in the bearers practically does not affect the dynamic values. Clearance changes in the bearers, located diagonally across the body, also do not affect the above mentioned values and the stability coefficients.

The change of clearances, located on the one side from $5 \mathrm{~mm}$ to 0 does not essentially affect the stability coefficient only, when all others dynamics

(C) S. Myamlin, L. Neduzha, O. Ten, A. Shvets, 2013 
coefficients change within the clearance range from 5 to $0 \mathrm{~mm}$ and then become stable.

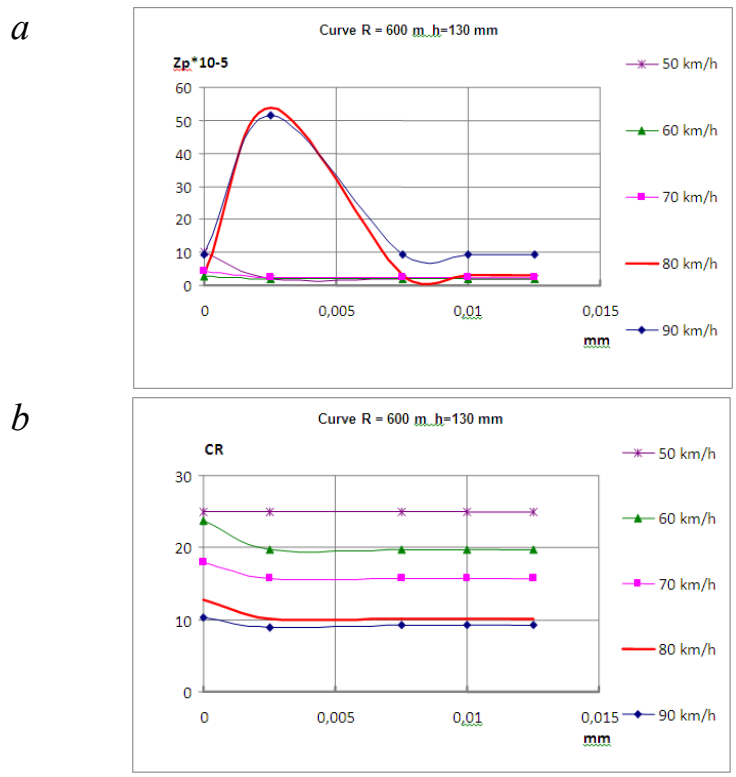

Fig. 5. Dependence of the vertical acceleration value in the center plate zone (a) and the resistance coefficient of the freight car (b) on the clearance in the bearer during motion in a curve with the radius $600 \mathrm{~m}$

$a$

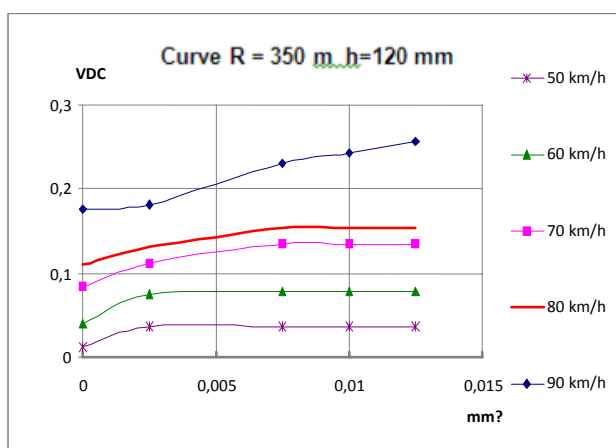

$b$

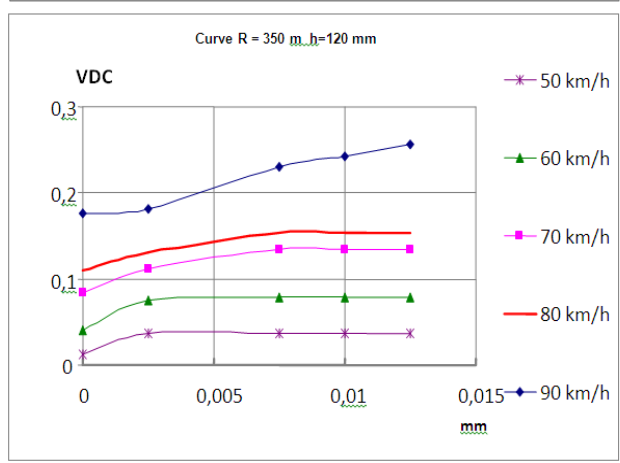

Fig. 6. Dependence of the vertical dynamics coefficient

(a) and the framed force (b) on the clearance in the bearer during motion in the curve with the radius $350 \mathrm{~m}$

During further increase of clearances in the bearers some degradation of the car dynamic load- ing occurs. Hence, the value of nominal clearances up to $5 \mathrm{~mm}$ is substantiated.

$a$

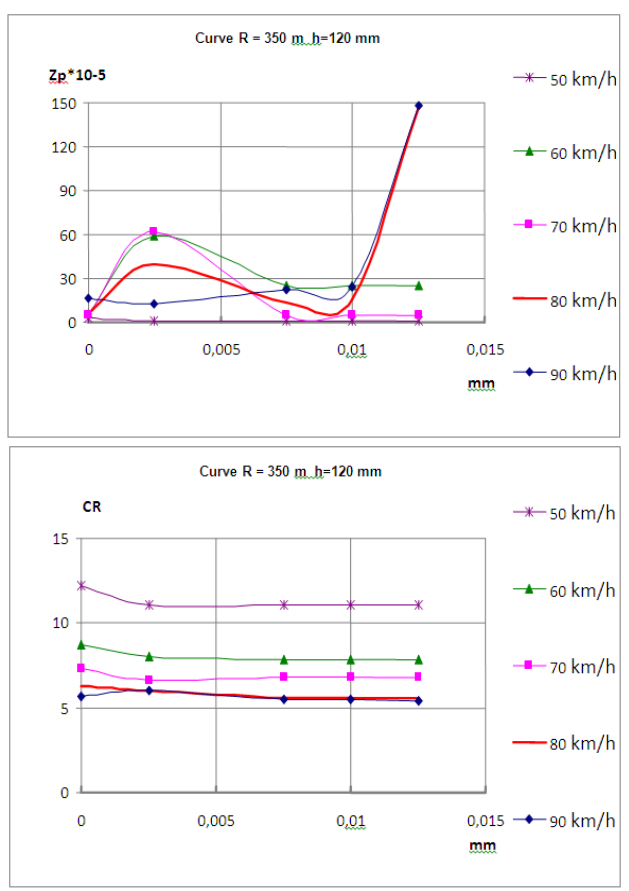

Fig. 7. Dependence of the vertical acceleration value in the center plate zone (a) and resistance coefficient (b) of the freight car on the clearance in bearer during motion in the curve with radius $350 \mathrm{~m}$

As a result of calculations, it is also established that the total longitudinal clearance less than $7 \mathrm{~mm}$ (transverse less than $5 \mathrm{~mm}$ ) is unacceptable. Since the "Standards" accept the minimal clearances: longitudinal clearance $-6 \mathrm{~mm}$, transverse clearance $-5 \mathrm{~mm}$, then these clearances are recommended to accept as the minimal ones.

In the research of the impact of deviations from normal condition of the bogie swing suspension wedge system on the dynamic loading of the car several conditions of the wedge system are studied $[4,9]$ :

- the normal condition, at which the damping factor is taken as 1 ;

- the condition of low friction that arises in the bogie design when the wedge is higher as compared to the normal condition; in that case the coefficient $\varphi$ is taken as 0.2 or 0.5

- overdamped condition of the system, at which the coefficient $\varphi$ is taken as 1.5 ;

- full absence of the friction in the system when the coefficient $\varphi$ is taken as 0 . 
Conclusions. As a result of the research the dependencies of the eight-wheel freight car on the bearer parameters, taking into account the running speed were obtained. Thus, the resulted calculations allow for an objective assessment the impact of the technical condition of the car running gears on the traffic safety factors.

\section{LIST OF REFERENCE LINKS}

1. Вериго, М. Ф. Взаимодействие пути и подвижного состава / М. Ф. Вериго, А. Я. Коган. - М. : Транспорт, 1986. - 560 с.

2. Данович, В. Д. Определение допускаемых скоростей движения грузовых вагонов по ж.-д. путям колеи 1520 мм / В. Д. Данович, В. В. Рыбкин, С. В. Мямлин, А. Г. Рейдемейстер, А. Г. Трякин, Н. В. Халипова // Вісник Дніпропетр. нац. ун-ту залізн. трансп. ім. акад. В. Лазаряна - Д. : ДНУЗТ, 2003. - Вип. 2. - С. 77-86.

3. Костюк, М. Д. Железнодорожный потенциал Украины / М. Костюк // Евразия. Вести. - 2009. - № 11. - С. 14.

4. Луханин, Н. И. Динамика грузовых вагонов с учетом поперечного смещения тележек /
Н. И. Луханин, С. В. Мямлин, Л. А. Недужая, А. А. Швец / Зб. наук. праць ДонІЗТ. - 2012. Вип. 29. - С. 234-241.

5. Нормы для расчета и проектирования вагонов железных дорог МПС колеи 1520 мм (несамоходных). - М. : ГосНИИВ - ВНИИЖТ, 1996. $352 \mathrm{c}$.

6. Свидетельство о регистрации авторского права на произведение №7305. Компьютерная программа «Dynamics of Rail Vihscles» («DYNRAIL») / Мямлин C. В.; зарегистр. 20.03.2003.

7. Сергиенко, Н. И. Состояние и перспективы развития вагонного хозяйства Укрзализныци / Н. И. Сергиенко // Вагонный парк. - 2011. № 9. - С. 4-13.

8. Шадур, Л. А. Вагоны: Конструкция, теория и расчет : учебник для ВУЗов ж.-д. трансп. / ред. Л. А. Шадура. - М. : Транспорт, 1980. - 440 с.

9. Myamlin, S. Spatial Vibration of Cargo Cars in Computer Modelling with the Account of Their Inertia Properties / S. Myamlin, A. Ten, L. Neduzha, A. Shvets // Mechanika $2010 \quad(8.04 .2010 \quad-$ 9.04.2010) : proc. of 15th International Conference. - Kaunas : Kaunas University of Technology, 2010. - P. 325-328.

\section{С. В. МЯМЛИН ${ }^{1}$, Л. А. НЕДУЖАЯ ${ }^{2 *}$, А. А. ТЕН ${ }^{3}$, А. А. ШВЕЦ ${ }^{2}$}

\footnotetext{
${ }^{1}$ Проректор по научной работе, Днепропетровский национальный университет железнодорожного транспорта имени академика В. Лазаряна, ул. Лазаряна, 2, 49010, Днепропетровск, Украина, тел./факс +38 (056) 79319 03, эл. почта sergeymyamlin@gmail.com

${ }^{2}$ ККаф. «Строительная механика», Днепропетровский национальный университет железнодорожного транспорта имени академика В. Лазаряна, ул. Лазаряна, 2, 49010, Днепропетровск, Украина, тел./факс +38 (056) 793 19 03, эл. почта nlorhen@i.ua

3 «Промтрактор-Вагон», ул. Ильича, 1a, 429332, Канаш, Российская Федерація, тел./факс +78 (83533) 2 55 65, эл. почта kvrz@cbx.ru
}

\section{ОПРЕДЕЛЕНИЕ ДИНАМИЧЕСКИХ ПОКАЗАТЕЛЕЙ ГРУЗОВЫХ ВАГОНОВ С УЧЕТОМ ТЕХНИЧЕСКОГО СОСТОЯНИЯ СКОЛЬЗУНОВ}

Цель. Железнодорожный транспорт играет важную роль в социально-экономической жизни государства и осуществляет большой объем перевозочной работы. Транспортная отрасль должна двигаться в направлении инновационных изменений, повышать свое значение как важной транзитной подсистемы на пути обновления не только инфраструктуры, но и стратегии всех составляющих перевозочного процесса, в том числе и при работе во взаимосвязи с другими видами транспорта. На современном этапе жизнь ставит перед железнодорожной отраслью стратегические задачи, основные среди которых: развитие скоростного движения поездов, увеличение массы грузовых поездов, разработка нового подвижного состава и т. п. В связи с актуальностью данной тематики перед учеными поставлена задача, посвященная одному из аспектов повышения эффективности грузовых перевозок, а именно - исследованию влияния различных факторов и характеристик технического состояния ходовых частей грузовых вагонов (которые неизбежно возникают при их эксплуатации) на их основные динамические показатели. Среди них важную роль играют и отклонения технического состояния ходовых частей от нормального состояния клиновой системы рессорного подвешива- 
ния тележки. Цель данной работы посвящена исследованию влияния различных факторов технического состояния ходовых частей грузовых вагонов (отклонение размеров как в скользунах, так и в клиновой системе во время эксплуатации) на их основные показатели - коэффициенты горизонтальной и вертикальной динамики, ускорение кузова, рамная сила, коэффициент устойчивости от схода с рельсов. Методика. Исследование проводилось методом численного интегрирования и математического моделирования динамической нагруженности грузового вагона с использованием программного комплекса «Dynamics of Rail Vehicles» («DYNRAIL»). Результаты. В результате исследований по определению динамических показателей грузовых вагонов с учетом технического состояния скользунов получены зависимости основных динамических показателей грузового вагона от параметров скользунов (зазоров в скользунах и состояния клиновой системы рессорного подвешивания тележек) с учетом скорости движения в прямых и кривых малого и среднего радиуса участков пути. Научная новизна. Определено влияние технического состояния ходовых частей вагона на факторы безопасности движения. Практическая значимость. Результаты теоретических исследований по определению динамических показателей грузовых вагонов с учетом технического состояния скользунов грузовых вагонов позволяют объективно оценить влияние технического состояния тележек грузовых вагонов в части параметров скользунов на показатели безопасности движения на железной дороге (коэффициенты горизонтальной и вертикальной динамики, ускорение кузова, рамная сила, коэффициент устойчивости от схода с рельсов).

Ключевые слова: грузовые вагоны; скользуны тележек; скорость движения; прямые и кривые участки пути; динамические показатели

\section{С. В. МЯМЛІН ${ }^{1}$, Л. О. НЕДУЖА ${ }^{2 *}$, О. О. ТЕН ${ }^{3}$, А. О. ШВЕЦЬ ${ }^{2}$}

${ }^{1}$ Проректор з наукової роботи, Дніпропетровський національний університет залізничного транспорту імені академіка В. Лазаряна, вул. Лазаряна, 2, 49010, Дніпропетровськ, Україна, тел./факс. +38 (056) 79319 03, ел. пошта sergeymyamlin@gmail.com

2 *Каф. «Будівельна механіка», Дніпропетровський національний університет залізничного транспорту імені академіка В. Лазаряна, вул. Лазаряна, 2, 49010, Дніпропетровськ, Україна, тел./факс. +38 (056) 79319 03, ел. пошта nlorhen@i.ua ${ }^{3}$ «Промтрактор-Вагон», вул. Илліча, 1а, 429332, Канаш, Російська Федерація, тел./факс +78 (83533) 255 65, ел. пошта kvrz@cbx.ru

\section{ВИЗНАЧЕННЯ ДИНАМІЧНИХ ПОКАЗНИКІВ ВАНТАЖНИХ ВАГОНІВ 3 УРАХУВАННЯМ ТЕХНІЧНОГО СТАНУ КОВЗУНІВ}

Мета. Залізничний транспорт відіграє важливу роль у соціально-економічному житті держави та здійснює великий обсяг перевізної роботи. Транспортна галузь повинна рухатися в напрямку інноваційних змін, підвищувати своє значення як важливої транзитної підсистеми на шляху оновлення не тільки інфраструктури, а й стратегії всіх складових перевізного процесу, в тому числі і при роботі у взаємозв'язку з іншими видами транспорту. На сучасному етапі життя ставить перед залізничною галуззю стратегічні задачі, основні серед яких: розвиток швидкісного руху поїздів, збільшення маси вантажних поїздів, розробка нового рухомого складу тощо. В зв'язку з актуальністю цієї тематики перед науковцями поставлена задача, присвячена одному з аспектів підвищення ефективності вантажних перевезень, а саме - дослідженню впливу різних факторів та характеристик технічного стану ходових частин вантажних вагонів (які неминуче виникають при їх експлуатації) на їх основні динамічні показники. Серед них важливу роль відіграє і відхилення технічного стану ходових частин від нормального стану клинової системи ресорного підвішування візка. Мета даної роботи присвячена дослідженню впливу різних факторів технічного стану ходових частин вантажних вагонів (відхилення розмірів як в ковзунах, так і в клиновій системі під час експлуатації) на їх основні показники - коефіцієнти горизонтальної та вертикальної динаміки, прискорення кузову, рамна сила, коефіцієнт стійкості від сходу з рейок. Методика. Дослідження проводилось методом чисельного інтегрування та математичного моделювання динамічної завантаженості вантажного вагону з використанням програмного комплексу «Dynamics of Rail Vehicles» («DYNRAIL»). Результати. В результаті досліджень щодо визначення динамічних показників вантажних вагонів з урахуванням технічного стану ковзунів отримано залежності основних динамічних показників, вантажного вагону від параметрів ковзунів (зазорів в ковзунах та стану клинової системи ресорного підвішування візків) з урахуванням швидкості руху на прямих та кривих малого та середнього радіусу ділянках колії. Наукова новизна. Визначено вплив технічного стану ходових частин вагона 
на фактори безпеки руху. Практична значимість. Результати теоретичних досліджень щодо визначення динамічних показників вантажних вагонів з урахуванням технічного стану ковзунів дозволяють об єктивно оцінити вплив технічного стану візків вантажних вагонів в частині параметрів ковзунів на показники безпеки руху на залізниці (коефіцієнти горизонтальної та вертикальної динаміки, прискорення кузову, рамна сила, коефіцієнт стійкості від сходу з рейок).

Ключові слова: вантажні вагони; ковзуни візків; швидкість руху; прямі та криві ділянки колії; динамічні показники

\section{REFERENCES}

1. Verigo M.F., Kogan A.Ya. Vzaimodeystviye puti i podvizhnogo sostava [Railway track and rolling stock interaction]. Moscow, Transport Publ., 1986. 560 p.

2. Danovich V.D., Rybkin V.V., Myamlin S.V., Reydemeyster A.G., Tryakin A.G., Khalipova N.V. Opredeleniye dopuskaemykh skorostey dvizheniya gruzovykh vagonov po zh.-d. putyam kolei $1520 \mathrm{~mm}$ [Permissible velocity determination of the freight cars on the railroads with the $1520 \mathrm{~mm}$.track]. Visnik Dnipropetrovskoho natsionalnoho universytetu zaliznychnoho transportu imeni akademika V. Lazaryana [Bulletin of Dnipropetrovsk National University of Railway Transport named after Academician V. Lazaryan], 2003, issue 2, pp. 7786.

3. Kostyuk M.D. Zheleznodorozhnyy potentsial Ukrainy [Railway potential of Ukraine]. Yevraziya. Vesti Eurasia. News, 2009, no. 11, pp. 14.

4. Lukhanin N.I., Myamlin S.V., Neduzhaya L.A., Shvets A.A. Dinamika gruzovykh vagonov s uchetom poperechnogo smeshcheniya telezhek [Freight cars dynamics, taking into account transversal displacement of the bogies]. Zbirnik naukovykh prats Donetskoho instytutu zaliznychnoho transportu -Proceedings of the Donetsk Railway Transport Institute, 2012, issue 29, pp. 234-241.

5. Normy dlya rascheta i proektirovaniya vagonov zheleznykh dorog MPS kolei $1520 \mathrm{~mm}$ (nesamokhodnykh) [Standards for design and construction of railroads with $1520 \mathrm{~mm}$. track cars (non-self-propelled)]. Moscow, GosNIIV -VNIIZhT Publ., 1996. 352 p.

6. Myamlin S.V. Computer«Dynamics of Rail Vihscles » («DYNRAIL»). Certificate of copyright registration on the invention, no. 7305, 2003.

7. Sergiyenko N.I. Sostoyaniye i perspektivy razvitiya vagonnogo khozyaystva Ukrzaliznytsi [Condition and development prospects for Ukrzalinytsia's car facilities]. Vagonnyy park - Wagon fleet, 2011, no. 9, pp. 4-13.

8. Shadur L.A. Vagony: Konstruktsiya, teoriya i raschet [Cars: construction, theory and calculation]. Moscow, Transport Publ., 1980. 440 p.

9. Myamlin S., Ten A., Neduzha L., Shvets A. Spatial Vibration of Cargo Cars in Computer Modelling with the Account of Their Inertia Properties. Proceedings of 15th International Conference "Mechanika 2010". Kaunas, 2010, pp. 325-328.

Prof. V. L. Horobets, D.Sc. (Tech); Prof. O. O. Beygul, D.Sc. (Tech) recommended this article to be published

Received 13.12.2012

Accepted 22.02.2013 